Aisyah Journal of Informatics and Electrical Engineering Universitas Aisvah Pringsewu

Journal Homepage

http://jti.aisyahuniversity.ac.id/index.php/AJIEE

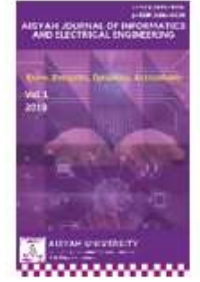

\title{
PENERAPAN METODE LOGIKA FUZZY DALAM MENGETAHUI KECERDASAN MENGATASI MASALAH PELAMAR KERJA MELALUI TES ADVERSITY QUOTIENT (AQ)
}

Dwi Yana Ayu Andini ${ }^{1}$, Zulkifli $^{2}$, Fadzlan Thoriq $^{3}$

${ }^{1,2,3}$ Program Studi Teknik Informatika, Fakultas Teknologi dan Informatika Universitas Aisyah Pringsewu dwiandini983@gmail.com

\begin{abstract}
ABSTRAK
Adversity Quotient (AQ) dapat berperan dalam memberikan gambaran kepada individual berkaitan dengan seberapa jauh individual mampu bertahan menghadapi kesulitan dan mampu untuk mengatasinya. AQ merupakan salah satu faktor yang dapat dipakai untuk mendukung kesuksesan, selain IQ yang tinggi atau EQ yang bagus. Sistem pendukung keputusan sebagai sebuah sistem berbasis komputer yang membantu dalam proses pengembilan keputusan. Pada penelitian ini diusulkan suatu pendekatan dalam menghitung nilai antara jumlah nilai tes $A Q$ dengan pendidikan yang telah ditempuh dengan metode fuzzy tsukamoto. Hasil pengujian didapat bahwa seseorang yang memiliki pendidikan rendah maka kemampuan mengatasi masalahnya sedang, sedangkan pendidikan sedang maka kemampuan mengatasi masalahnya sedang, dan pendidikan tinggi maka kemampuan mengatasi masalahnya tinggi. Metode sampel yang digunakan adalah judgment sampling yaitu sampel yang dipilih atau diterapkan berdasarkan kesesuaiannya dengan tujuan penelitian.
\end{abstract}

Kata Kunci: Adversity Quotient, Fuzzy Tsukamoto 


\section{PENDAHULUAN}

A. Latar Belakang

Kesuksesan adalah tingkat seseorang bergerak kedepan dan keatas, terus maju dalam menjalani hidup, kendati terdapat berbagai rintangan atau bentuk kesengsaraan (Stoltz, 2000). Untuk mencapai kesuksesan dalam hidup, diantaranya ditentukan oleh Adversity Quotient (AQ) yang dimiliki setiap orang. Pada penelitian terdahulu menyatakan bahwa masih banyak perusahaan yang melakukan tes IQ kepala calon pekerja. Padahal kecerdasan bukan menjadi tolak ukur keberhasilan seseorang (Laura, 2009).

Untuk menentukan seseorang mempunyai tingkat kecerdasan dalam mengatasi masalah tinggi atau rendahnya, tidak hanya ditentukan oleh mengikuti tes AQ ini saja. Melainkan ada faktor pendukung lainnya, salah satu faktor tersebut adalah pendidikan yang telah ditempuh. Dalam penelitian ini penulis menggunakan metode fuzzy tsukamoto. Fuzzy tsukamoto digunakan untuk menghitung nilai hasil keputusan (z) dari suatu permasalahan. Yang merepresentasikan suatu input ke ruang output dengan aturan berbentuk IF-THEN dengan fungsi keanggotaan yang direpresentasikan dengan ruang keadaan pada suatu sample dan hasil akhir yang diperoleh berupa nilai keputusan sebagai rata-rata terbobot (z) (Aryanto \& Pujiyanta, 2013).

Untuk mendapatkan hasil dari AQ terdapat tiga faktor yang digunakan dalam penelitian ini yaitu tes respons profil adversity, tes kemampuan mengatasi masalah, dan pendidikan. Hasil dari studi kasus tersebut adalah seseorang yang memiliki pendidikan rendah maka kemampuan mengatasi masalahnya sedang, sedangkan pendidikan sedang maka kemampuan mengatasi masalahnya sedang, dan pendidikan tinggi maka kemampuan mengatasi masalahnya tinggi.

\section{B. Rumusan Masalah}

Berdasarkan latar belakang masalah yang telah dijelaskan diatas, maka rumusan masalah dari penelitian ini adalah:

1. Bagaimana menghitung hasil dari tes kemampuan mengatasi masalah dengan faktor pendidikan menggunakan metode tsukamoto?

2. Bagaimana menentukan bahwa orang tersebut mempunyai tingkat kecerdasan rendah, sedang, dan tinggi?

C. Batasan Masalah

Adapun batasan-batasan permasalahan yang ada adalah sebagai berikut :

1. Data yang digunakan adalah data soal tes respons profil adversity, tes kemampuan mengatasi masalah

2. Faktor pendukung kecerdasan mengatasi masalah menggunakan faktor pendidikan.

3. Fungsi keanggotaan yang digunakan adalah fungsi keanggotaan linear.

4. Metode yang digunakan adalah metode fuzzy tsukamoto.

D. Tujuan

Tujuan dari penelitian ini adalah:

1. Menghitung hasil dari tes kemampuan mengatasi masalah dengan faktor pendidikan menggunakan pendekatan fuzzy tsukamoto.

2. Mengetahui kecerdasan mengatasi masalah pelamar kerja dengan faktor pendukung seperti pendidikan.

E. Manfaat Penelitian

Manfaat dari penelitian ini adalah :

1. Untuk peneliti berupa pengalaman bagaimana mengetahui kecerdasan seseorang dalam mengatasi masalah dengan menggunakan metode fuzzy tsukamoto dan beberapa metode penelitian serta menambah referensi.

2. Membantu perusahaan dalam mendapatkan pelamar kerja yang sesuai dengan yang dibutuhkan oleh perusahaan tersebut. 


\section{LANDASAN TEORI}

\section{A. Adversity Quotient}

Menurut Prasetyono, Dwi Sunar (2013), Adversity Quotient (AQ) adalah kecerdasan menghadapi kesulitan atau hambatan, kemampuan bertahan dalam berbagai kesulitan hidup dan tantangan yang dialami. Adversity Quotient dapat menjadi indikator seberapa kuatkah seseorang dapat terus bertahan dalam suatu pergumulan, sampai pada akhirnya orang tersebut dapat keluar sebagai pemenang, mundur ditengah jalan, atau bahkan tidak mau menerima tantangan sedikit pun.

\section{B. Sistem Pendukung Keputusan}

Sistem pendukung keputusan (SPK) sebagai sebuah sistem berbasis komputer yang membantu dalam proses pengembilan keputusan. Sistem pendukung keputusan sebagai sistem informasi berbasis komputer yang adaptif, interaktif, fleksibel, yang secara khusus dikembangkan untuk mendukung solusi dari permasalahan manajemen yang tidak terstruktur untuk meningkatkan kualitas pengambilan keputusan (Henry dkk, 2009).

\section{Himpunan Fuzzy}

Pada himpunan tegas (crisp), nilai keanggotaan suatu item $\mathrm{x}$ dalam suatu himpunan $\mathrm{A}$, yang sering ditulis dengan $\mu_{\mathrm{A}}$ [x], memiliki dua kemungkinan yaitu:

1. Satu (1), yang berarti bahwa suatu item menjadi anggota dalam suatu himpunan, atau

2. No (0), yang berarti bahwa suatu item tidak menjadi anggota dalam suatu himpunan

\section{Fungsi Keanggotaan}

Fungsi keanggotaan (membership function) adalah suatu kurva yang menunjukkan pemetaan titik-titik input data ke dalam nilai keanggotaannya (sering juga disebut dengan derajat kenggotaan) yang memiliki interval antara 0 sampai 1. Salah satu cara yang dapat digunakan untuk mendapatkan nilai keanggotaan adalah dengan melalui pendekatan fungsi. Ada beberapa fungsi yang digunakan.

1. Representasi Linear

Pada representasi linear, pemetaan input ke derajat keanggotaannya digambarkan sebagai suatu garis lurus. Bentuk ini paling sederhana dan menjadi pilihan yang baik untuk mendekati suatu konsep yang kurang jelas. Ada dua keadaan himpunan fuzzy yang linear. Pertama, kenaikan himpunan dimulai pada nilai domain yang memiliki derajat keanggotaan nol [0] bergerak ke kanan menuju ke nilai domain yang memiliki derajat keanggotaan lebih tinggi.

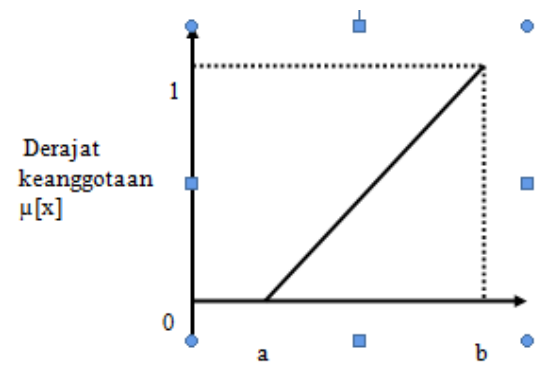

Fungsi Keanggotaan:

$$
\mu(x)=\left\{\begin{array}{cc}
0 ; & x \leq a \\
(x-a) /(b-a) & a \leq x \leq b \\
1 ; & x \geq b
\end{array}\right.
$$

Kedua, merupakan kebalikan yang pertama. Garis lurus dimulai dari nilai domain dengan derajat keanggotaan tertinggi pada sisi kiri, kemudian bergerak menurun ke nilai domain yang memiliki derajat keanggotaan lebih rendah.

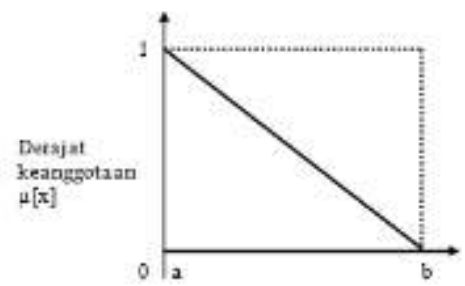

Gambar 2.2 Representasi Linear Turun

Fungsi Keanggotaan : 


$$
\mu(x)=\left\{\begin{array}{cc}
1 ; & x \leq a \\
(b-x) /(b-a) & a \leq x \leq b \\
0 ; & x \geq b
\end{array}\right.
$$

E. Sistem Inferensi Fuzzy Tsukamoto

Menurut Kusumadewi (2003), pada metode tsukamoto, setiap konsekuen pada aturan yang berbentuk IF-THEN harus direpresentasikan dengan suatu himpunan fuzzy dengan fungsi keanggotaan yang monoton. Sebagai hasilnya, output hasil inferensi dari tiap-tiap aturan diberikan secara tegas (crips) berdasarkan $\alpha$-predikat (file strength). Hasil akhirnya diperoleh dengan menggunakan rata-rata terbobot.

Misalkan ada dua variabel input, var-1 (x) dan var-2 (y), serta satu variabel output, var-3 (z), dimana var-1 terbagi atas dua himpunan yaitu $A_{1}$ dan $A_{2}$ terbagi atas dua himpunan $B_{1}$ dan $B_{2}$, var-3 juga terbagi atas dua himpunan yaitu $\mathrm{C}_{1}$ dan $\mathrm{C}_{2}\left(\mathrm{C}_{1}\right.$ dan $\mathrm{C}_{2}$ harus monoton). Ada dua aturan yang digunakan, yaitu:

[R1] IF ( $\mathrm{x}$ is $\mathrm{A}_{1}$ ) and ( $\mathrm{y}$ is $\mathrm{B}_{2}$ ) THEN ( $\mathrm{z}$ is $\mathrm{C}_{1}$ )

[R2] IF ( $\mathrm{x}$ is $\mathrm{A}_{2}$ ) and ( $\mathrm{y}$ is $\left.\mathrm{B}_{1}\right)$ THEN ( $\mathrm{z}$ is $\mathrm{C}_{2}$ )

Alur inferensi seperti untuk mendapatkan satu nilai crisp z seperti terlihat pada gambar dibawah ini.
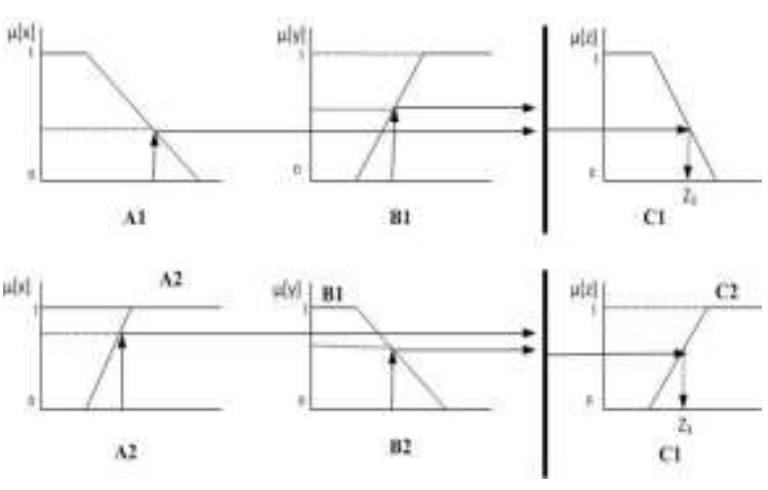

Gambar 2.3 Alur Inferensi Fuzzy Tsukamoto

\section{METODE PENELITIAN}

A. Tahapan Penelitian

Tahapan penelitian adalah lanjutan dari kerangka penelitian, dan terbagi lagi menjadi beberapa sub menu bagian. Tahapan penelitian dapat dilihat pada gambar berikut:

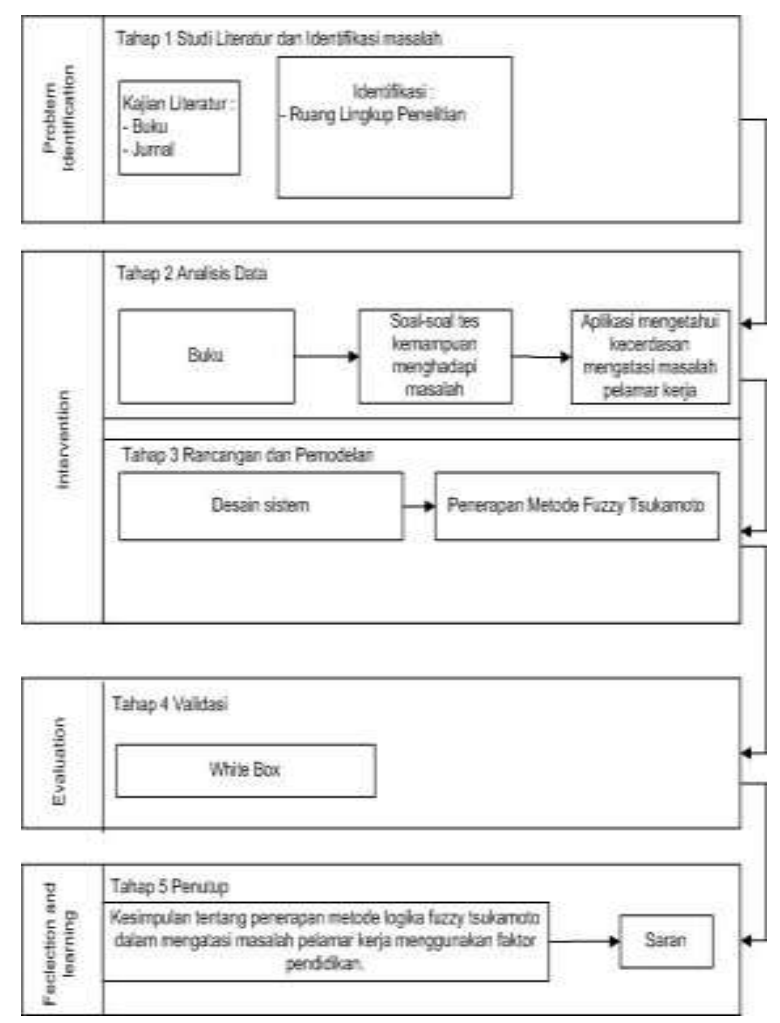

Gambar 3.1 Tahapan Penelitian

\section{B. Analisis}

Pada penelitian ini digunakan tiga variabel input yaitu respons profil tes, tes kemampuan menghadapi masalah, dan pendidikan sebagai crisp sets yang akan dijadikan fuzzy sets, serta satu output yaitu adversity quotient.

Pada metode fuzzy tsukamoto, langkah selanjutnya adalah membuat himpunan fuzzy dan mendefinisikan variabel input dan output, yaitu :

a. Variabel input adalah respons profil tes, tes kemampuan menghadapi masalah, dan pendidikan, terdiri atas 3 himpunan fuzzy yaitu : rendah, sedang, tinggi.

b. Variabel output adalah adversity quotient, terdiri atas 3 himpunan fuzzy yaitu : rendah, sedang, tinggi. 
Persamaan fungsi keanggotaan yang digunakan adalah fungsi keanggotaan linear. Berikut adalah fungsi keanggotaan (membership function) dari masing-masing himpunan input fuzzy diatas.

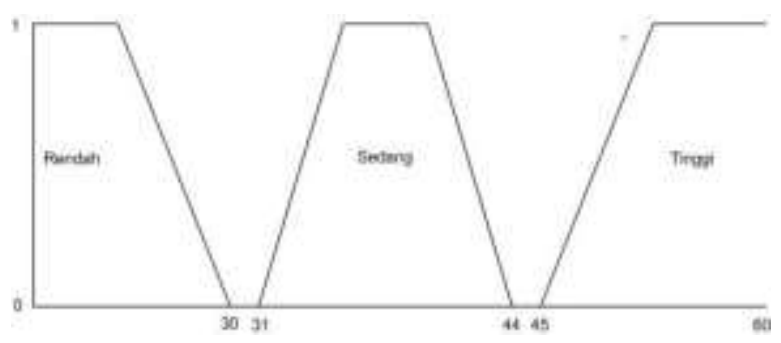

Gambar 3.2 Himpunan fuzzy nilai variabel kemampuan mengatasi masalah

$$
\mu K M M \operatorname{rendah}(y)=\left\{\begin{array}{cc}
\frac{b-y}{b-a} & 30 \leq y \leq 15 \\
0 ; & y \geq 30
\end{array}\right.
$$

$$
\mu K M M \text { sedang }(y)=\left\{\begin{array}{cc}
\frac{b-y}{b-a} & 31 \leq y \leq 44 \\
0 ; & y \geq 44
\end{array}\right.
$$$$
\mu K M M \text { tinggi }(y)=\left\{\begin{array}{cc}
0 ; & y \leq 45 \\
(y-a) /(b-a) & 45 \leq y \leq 60 \\
1 ; & y \geq 60
\end{array}\right.
$$

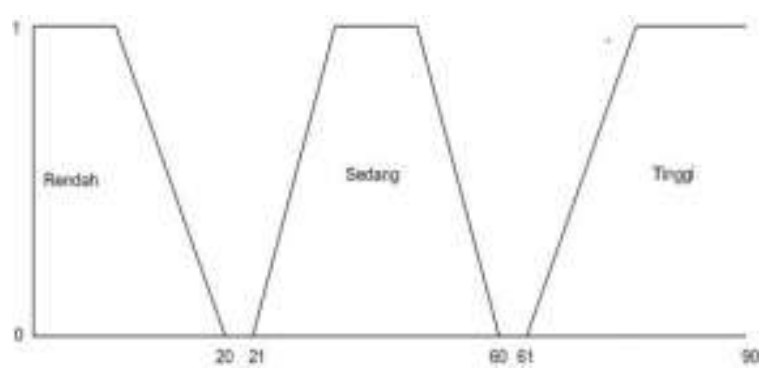

Gambar 3.4 Himpunan fuzzy nilai input variabel pendidikan

$$
\text { upend rendah }(x)=\left\{\begin{array}{cc}
\frac{b-x}{b-a} & 10 \leq x \leq 20 \\
0 ; & x \geq 10
\end{array}\right.
$$$$
\text { upend sedang }(x)=\left\{\begin{array}{cc}
\frac{b-x}{b-a} & 21 \leq x \leq 60 \\
0 ; & x \geq 60
\end{array}\right.
$$$$
\text { upend tinggi }(x)=\left\{\begin{array}{cc}
0 ; & x \leq 61 \\
(x-a) /(b-a) & 61 \leq x \leq 90 \\
1 ; & x \geq 90
\end{array}\right.
$$

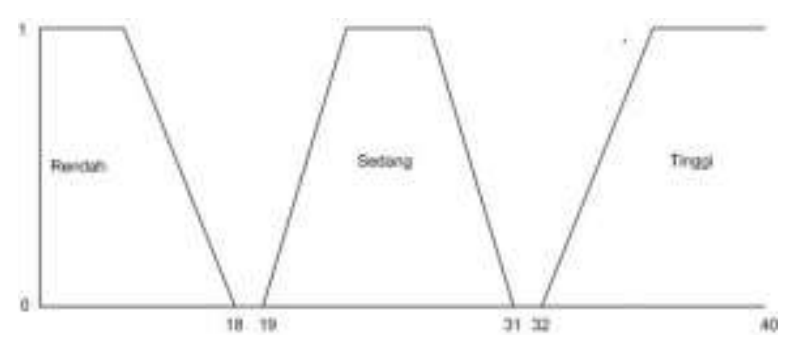

Gambar 3.5 Himpunan fuzzy nilai input variabel Respons Profil

$$
\begin{gathered}
\mu R P \operatorname{rendah}(q)=\left\{\begin{array}{cc}
\frac{b-q}{b-a} & 8 \leq q \leq 18 \\
0 ; & q \geq 8
\end{array}\right. \\
\mu R P \operatorname{sedang}(q)=\left\{\begin{array}{cc}
0 ; & q \leq 19 \\
(q-a) /(b-a) & 19 \leq q \leq 31 \\
1 ; & q \geq 31
\end{array}\right. \\
\mu R P \operatorname{ting} i(q)=\left\{\begin{array}{cc}
0 ; & q \leq 32 \\
(q-a) /(b-a) & 32 \leq q \leq 40 \\
1 ; & q \geq 40
\end{array}\right.
\end{gathered}
$$

Pada metode tsukamoto, setiap konsekuensi pada aturan yang berbentuk IFThen, harus direpresentasikan dengan suatu himpunan fuzzy dengan fungsi keanggotaan yang monoton. Sebagai hasilnya, output hasil inferensi dari tiap-tiap aturan diberikan secara tegas (crisp) berdasarkan $\alpha$-predikat (file strength). Hasil akhirnya diperoleh dengan menggunkan rata-rata terbobot.

$$
\mathrm{Z}=\frac{(\alpha \text { predikat } 1 \times z 1)+(\alpha \text { predikat } 2 \times z 2)}{\alpha \text { predikat } 1+\alpha \text { predikat } 2}
$$

Dalam Adversity Quotient terdapat beberapa pertanyaan yang harus dijawab oleh para pelamar kerja, beberapa pertanyaan tersebut dibagi menjadi 2 kategori tes. Tes tersebut yaitu: tes respons profil adversity dan tes kemampuan menghadapi masalah. Pertanyaan-pertanyaanya sebagai berikut :

\section{Tes Respons Profil Adversity}

\section{Penilaian Skor}

Respons profil AQ Anda terdiri dari empat dimensi CORE. Pemahaman ini merupakan langkah pertama meningkatkan respons Anda terhadap kesulitan, memperluas kapasitas Anda, dan pada akhirnya meningkatkan AQ secara keseluruhan. Masukkan masing-masing 20 
angka yang telah Anda lingkari pada respons profil dalam kotak sesuai dibawah ini. Kemudian jumlahkan untuk setiap kolom, lalu tambahkan hasil penjumlahan tadi, selanjutnya kalikan jumlah tersebut dengan dua untuk skor akhir Anda.

\begin{tabular}{|c|c|c|c|}
\hline $\mathbf{C}$ & $\mathbf{O}$ & $\mathbf{R}$ & $\mathbf{E}$ \\
\hline 1 & 2 & 3 & 4 \\
\hline 7 & 6 & 5 & 8 \\
\hline 13 & 11 & 9 & 10 \\
\hline 15 & 16 & 12 & 14 \\
\hline 17 & 18 & 20 & 19 \\
\hline $\begin{array}{l}\text { Total } \\
\mathbf{C}=\ldots\end{array}$ & $\begin{array}{l}\text { Total } \\
\mathbf{O}=\ldots\end{array}$ & $\begin{array}{l}\text { Total } \\
\mathbf{R}=\ldots\end{array}$ & $\begin{array}{l}\text { Total } \\
\text { Total }((\mathbf{C}+\mathbf{O}+\mathbf{R}+\mathbf{E}) * \mathbf{2})=\ldots\end{array}$ \\
\hline
\end{tabular}

\section{Analisis AQ Anda}

AQ rendah (8-18) menunjukkan bahwa Anda memiliki waktu yang sulit dalam menghadapi kesulitan.

AQ sedang (19-31) menunjukkan Anda menghadapi kesulitan Sedang baik, namun kinerja Anda dapat ditingkatkan dengan AQ yang lebih tinggi.

AQ tinggi (32-40) menunjukkan toleransi yang tinggi untuk kesulitan dan kemampuan untuk bertahap melalui perubahan jaman.

\section{Tes Kemampuan Menghadapi Masalah}

\section{Penilaian}

Beri nilai 2 untuk setiap jawaban " $C$ ", nilai 1 untuk setiap jawaban "A", dan nilai 0 untuk setiap jawaban "B".

\section{Skor}

45-60 : Sangat Tenang

31-44 : Sedang Tenang

$<30 \quad$ : Kurang Tenang

\section{HASIL DAN PENGUJIAN}

A. Hasil
Aplikasi yang dibuat akan digunakan oleh perusahaan sebagai alat bantu dalam menentukan kecerdasan mengatasi masalah pelamar kerja bedasarkan pendidikan dan jumlah nilai yang didapat dari tes Adversity Quotient. Program ini dibuat menggunakan NeatBeans IDE 7.0 dan database $M y S q l$ sebagai basis datanya. Berikut merupakan penjelasan dari setiap komponen pada aplikasi kecerdasan mengatasi masalah pelamar kerja.

\section{B. Pengujian akurasi}

Nilai akurasi didapatkan dari data uji melalui tes kecerdasan mengatasi masalah dan juga data sebenarnya.

Nilai akurasi didapat dari:

$$
\begin{aligned}
\text { Akurasi (\%) } & =\frac{\text { Data Uji Benar }}{\text { Total Data Uji }} \times 100 \% \\
& =\frac{10}{17} \times 100 \% \\
& =58,82 \%
\end{aligned}
$$

Jadi, nilai akurasi yang didapatkan yaitu sebesar $35,29 \%$.

\section{KESIMPULAN DAN SARAN}

\section{A. Kesimpulan}

Berdasarkan rumusan masalah dan pembahasan serta hasil penelitian tentang penerapan metode logika fuzzy dalam mengetahui kecerdasan mengatasi masalah pelamar kerja menggunakan adversity quotient maka dapat diambil kesimpulan sebagai berikut:

1. Untuk menghitung hasil dari tes kemampuan mengatasi masalah dengan pendidikan menggunakan langkah-langkah perhitungan dari metode fuzzy tsukamoto. Langkah pertama tentukan variabel-variabel pendukung atau variabel yang akan digunakan, kemudian mencari nilai keanggotaannya, dan langkah terakhir adalah menentukan ratarata terbobot (defuzzyfikasi). 
2. Untuk menentukan bahwa seseorang mempunyai tingkat kecerdasan rendah, sedang, dan tinggi yaitu dengan cara melihat hasil tes kemampuan mengatasi masalah dan respons profil, serta tingkat pendidikan yang telah ditempuh.

3. Hasil pengujian berdasarkan perhitungan didapat bahwa seseorang yang memiliki pendidikan rendah maka kemampuan mengatasi masalahnya sedang, sedangkan pendidikan sedang maka kemampuan mengatasi masalahnya sedang, dan pendidikan tinggi maka kemampuan mengatasi masalahnya tinggi.

4. Nilai akurasi dari penelitian ini adalah 58,82 \%, dengan jumlah sampel yang ditentukan oleh peneliti. Sampel tersebut termasuk dalam metode porposive sampling atau judgment sampling.

\section{B. Saran}

Beberapa saran yang dapat diberikan berdasarkan pembahasan diatas:

1. Pada penelitian selanjutnya diharapkan mengunakan faktor pendukung lebih dari dua faktor dan menggunakan metode lain dalam penerapanya misalkan menggunakan metode fuzzy mamdani.

2. Perbanyak data sampel atau data populasi yang akan diteliti, gunakan metode random sampling dalam menentukan sampel.

\section{DAFTAR PUSTAKA}

Amalia, Nanda, Yuni Yamasari, 2015, Rancang Bangun Sistem Pakar Identifikasi Penyakit Fisik Akibat Kerja dengan Metode Certainty Factor, Jurnal Ilmiah Manajemen Informatika, Vol 04 No 01 Tahun 2015.

Anjar, Nur Sari, 2013, Sistem Pakar Mendiagnosa Penyakit Demam Berdarah Menggunakan Metode Certainty Factor, Jurnal Ilmiah Teknik Informatika, Vol IV No 3 Agustus 2013.

Erdani, Yuliadi, 2008, Konsep Inferensi pada Model Pengetahuan Berbasis Ternary Grid, Jurnal Ilmiah SemnasIF 24 Mei 2008.

Hasibuan, Zaenal, 2007, Metodologi Penelitian pada Bidang Ilmu Komputer dan Teknologi Informasi Konsep Teknik dan Aplikasi, Jakarta, Fakultas Ilmu Komputer Universitas Indonesia.

Kusumadewi, S, 2003, Artificial Intelligence (Teknik dan Aplikasinya), Yogjakarta, Graha Ilmu.

Mardjono, Mahar, Priguna Sidharta, 2008, Neurologi Klinis Dasar, Jakarta, Dian Rakyat.

Mumenthaler, Mark, 1995, Neurologi Jilid 1, Jakarta, Binarupa Aksara.

Puppe, Frank, 1993, Systematic Introduction to Expert Systems Knowledge Representations and ProblemSolving Methods, Germany

Rohajawati, Siti, Rina Supriyati, 2010, Sistem Pakar : Diagnosis enyakit Unggas dengan Metode Certainty Factor, Jurnal Ilmiah CommIT, Vol 041 Mei 2010. 
Rohman, Feri Fahrur, Ami Fauzijah, 2008, Rancang Bangun Aplikasi Sistem Pakar untuk Menentukan Jenis Gangguan Perkembangan pada Anak, Jurnal Ilmiah Teknik Informatika, Vol 06 No 1 Juni 2008 : $1-23$. 